\title{
Pengaruh Model Pembelajaran OIDDE terhadap Kemampuan Berpikir Kritis Siswa Di SMAN 2 Berau Pada Materi Suhu dan Kalor
}

\author{
Ary Lasmana ${ }^{1 *}$, Riskan Qadar², dan Muliati Syam ${ }^{3}$ \\ 1,2,3 Program Studi Pendidikan Fisika Fakultas Keguruan dan Ilmu Pendidikan \\ Universitas Mulawarman, Samarinda-Indonesia \\ *E-mail : arylasmana09@gmail.com
}

\begin{abstract}
Abstrak
Penelitian ini bertujuan untuk mengetahui pengaruh model pembelajaran OIDDE terhadap kemampuan berpikir kritis siswa di SMAN 2 Berau pada materi suhu dan kalor. Penelitian ini merupakan penelitian kuantitatif dengan one-group pre-test post-test design. Populasi pada penelitian ini seluruh siswa kelas XI SMAN 2 Berau. Teknik pengambilan sampel adalah purposive sampling. Sampel penelitian ini adalah siswa kelas XI IPA 3 yang berjumlah 32 siswa. Instrumen penelitian yang digunakan merupakan instrumen tes tertulis berupa essai sebanyak 10 soal digunakan untuk mengukur kemampuan berpikir kritis pada materi suhu dan kalor. Berdasarkan analisis data diperoleh rata-rata pre-test siswa adalah 12,31 dan hasil rata-rata posttest adalah 61,31 serta hasil rata-rata $N$ Gain sebesar 0,56 kategori sedang. Berdasarkan hasil analisis uji-t berpasangan ditemukan bahwa terdapat perbedaan signifikan hasil pre-test dengan post-test. Dengan demikian, dapat disimpulkan bahwa terdapat pengaruh model pembelajaran OIDDE terhadap kemampuan berpikir kritis siswa di SMAN 2 Berau pada materi suhu dan kalor.
\end{abstract}

Kata kunci: Model Pembelajaran OIDDE, Kemampuan berpikir kritis, Suhu dan Kalor

\begin{abstract}
This study aims to determine the effect of the OIDDE learning model on students' critical thinking skills at SMAN 2 Berau on temperature and heat material. This research is a quantitative study with one-group pre-test post-test design. The population in this study all students of class XI SMAN 2 Berau. The sampling technique is purposive sampling. The sample of this study was 32 students of class XI IPA 3. The research instrument used was a written test instrument in the form of essays as many as 10 questions were used to measure critical thinking skills on the material temperature and heat. Based on data analysis, the average student pre-test was 12.31 and the posttest average score was 61.31 and the average N-Gain result was 0.56 included in the medium category. Based on the results of the paired t-test analysis it was found that there were significant differences in the pre-test and post-test results. Thus, it can be concluded that there is an influence of the OIDDE learning model on students' critical thinking skills at SMAN 2 Berau on temperature and heat.
\end{abstract}

Keywords: OIDDE Learning Model, Critical thinking skills, Temperature and Heat

Article History: Received: 30 Desember 2019

Revised : 20 Januari 2020

Accepted: 9 Januari 2020

Published: 31 Januari 2020

How to cite: Lasmana, A., Qadar, R., dan Syam, M. (2020). Pengaruh Model Pembelajaran OIDDE Terhadap Kemampuan Berpikir Kritis Siswa di SMAN 2 Berau pada Materi Suhu dan Kalor, 1(1). pp. 11-18. Retrieved from http://jurnal.fkip.unmul.ac.id/index.php/jpfp/index

Copyright (C) Januari 2020, Jurnal Literasi Pendidikan Fisika

\section{PENDAHULUAN}

Pendidikan merupakan usaha sadar dan terencana untuk mewujudkan suasana belajar dan proses pembelajaran agar siswa secara aktif mengembangkan potensi dirinya, sehingga memiliki kekuatan spiritual, kecerdasan, kepribadian, akhlak mulia, serta keterampilan 
Pengaruh Model Pembelajaran

yang diperlukan dirinya, masyarakat, bangsa, dan negara (UU RI No 20 Tahun 2003 tentang Sistem Pendidikan Nasional Pasal 1).

Selain itu pendidikan juga memegang peran yang sangat penting dalam peningkatan kualitas sumber daya manusia (SDM). Ini berarti berhasil atau tidaknya pencapaian tujuan pendidikan itu sangat bergantung pada proses belajar yang dialami siswa.

Dalam kegiatan belajar mengajar fisika, pemahaman konsep dalam diri siswa penting untuk ditingkatkan agar siswa dapat lebih mememahami tentang konsep fisika sehingga apabila dihadapkan dengan permasalahan atau soal fisika siswa dengan mudah dapat memecahkan permasalahan atau soal tersebut. Siswa tidak hanya menghafal rumus dasar dari materi saja, tetapi siswa lebih memahami pemahaman konsep dasar fisika yang dimiliki siswa sehingga siswa tidak lagi merasa terbebani dengan soal fisika.

Guru merupakan faktor penting dalam proses pembelajaran, karena guru yang akan berhadapan langsung dengan peserta didik dalam proses pembelajaran, melalui guru pula ilmu pengetahuan dapat ditransfer kepada peserta didik. Guru memiliki tanggung jawab besar yang mau tidak mau harus dilaksanakannya sebagai guru. Guru harus bertanggung jawab atas hasil kegiatan belajar siswa melalui interaksi selama proses pembelajaran berlangsung.

Guru merupakan faktor yang mempengaruhi berhasil atau tidaknya proses pembelajaran, dan karenanya guru harus menguasai prinsip-prinsip belajar di samping menguasai materi yang akan diajarkan. Dengan kata lain guru harus mampu menciptakan lingkungan belajar yang sebaikbaiknya. Guru sebagai pembimbing dalam proses pembelajaran harus menggunakan model pembelajaran yang tepat sebab pada pendidikan formal semua bidang pendidikan dan bidang studi harus memanfaatkan dasar mental pada tiap anak. Hal tersebut bertujuan untuk meningkatkan kemampuan mental kearah kematangan dan kedewasaan dalam arti seluasluasnya secara terarah dan teratur.
Hasil observasi yang telah dilakukan di SMAN 2 Berau banyak ditemui masalah-masalah yang terjadi dalam pembelajaran fisika misalnya: 1) proses pembelajaran yang dilaksanakan belum diarahkan untuk mengembangkan kemampuan berpikir kritis. Pembelajaran hanya dilaksanakan dengan ceramah, diskusi, dan penugasan tertentu dan tidak dirancang secara sengaja untuk mengembangkan kemampuan berpikir kritis; 2) peserta didik belum dikondisikan dalam sebuah pendekatan pembelajaran yang inovatif dan konstruktif, yang menekankan belajar kontekstual melalui kegiatan-kegiatan yang kompleks; 3) peserta didik belum dikondisikan pada situasi yang menantang atau masalah yang melibatkan solusi, pengambilan keputusan, refleksi, dan pengambilan inisiatif dengan difasilitasi guru; 4) motivasi peserta didik dalam belajar masih rendah, hal ini dapat diketahui dari ketidakantusiasan siswa dalam mengikuti proses pembelajaran, banyak peserta didik yang tidak memperhatikan penjelasan dosen maupun penjelasan temannya yang lain pada saat proses pembelajaran berlangsung; 5) peserta didik lebih tertarik atau senang ketika kegiatan pembelajaran berupa diskusi, namun kegiatan tersebut belum terkondisikan secara sistematis sehingga tidak terarah; 6) peserta didik belum diminta untuk mengaitkan pengetahuan yang telah miliki dengan materi yang akan mereka pelajari atau menyadari apa yang telah mereka ketahui dari materi yang akan dipelajari.

Dalam pembelajaran fisika, siswa diharuskan memiliki kemampuan kognitif dengan pemahaman konsep yang tinggi, agar materi yang disampaikan dapat diimplementasikan oleh siswa melalui pemrosesan informasi dan proses berpikir. Variasi perubahan pada proses pembelajaran, terlebih dalam model pembelajaran yang digunakan dapat menjadi salah satu cara untuk meningkatkan kemampuan tersebut. Model pembelajaran yang dapat mengontrol pertanyaan-pertanyaan yang diungkapkan, hipotesis yang dibuat dan apa yang siswa amati. Salah satu cara untuk meningkatkan kemampuan tersebut adalah dengan model pembelajaran OIDDE. Model pembelajaran OIDDE adalah akronim untuk 
Pengaruh Model Pembelajaran

Orientation, Identify, Discussion, Decision, dan Engage in behavior (Hudha, Amin, Sutiman, \& Akbar, 2016b)

Model pembelajaran yang diduga layak (valid), praktis dan efektif secara teoritis untuk diterapkan dalam pengembangan kemampuan berpikir kritis adalah model pembelajaran OIDDE (Husamah, Pantiwati, Huda, 2017). Model pembelajaran OIDDE (Orientation, Identify, Discussion, Decision, dan Engage in behavior) dimungkinkan mendukung teori bahwa pembelajaran yang diberikan harus meningkatkan aktivitas peserta didik untuk menemukan dan memecahkan masalah, bekerja kooperatif, memiliki sikap etis dan mampu mengambil keputusan etis atas problematika etis yang dihadapi (Hudha, Amin, Sumitro, \& Akbar, 2016a)

Semua indikator keterampilan berpikir kritis meningkat setiap siklusnya. Rerata kemampuan berpikir kritis mahasiswa meningkat dari $63,7 \%$ pada prasiklus menjadi $72,9 \%$ pada Siklus I menjadi $82,3 \%$ pada Siklus II peningkatan sebesar $9,4 \%$, total peningkatan kemampuan berpikir kritis dari prasiklus sampai Siklus II sebesar 18,6\% (Setyawan, 2017). Penerapan Model Pembelajaran OIDDE ini juga diterapkan pada pembelajaran dikelas dan dapat meningkatkan hasil belajar siswa dengan ketuntasan belajar $100 \%$.

Berdasarkan uraian di atas, maka penulis tertarik untuk mengadakan penilitian tentang "Pengaruh model pembelajaran OIDDE terhadap peningkatan berpikir kritis di SMAN 2 Berau materi suhu dan kalor".

\section{METODE}

Penelitian ini mengaplikasikan pendekatan penelitian kuantitatif dengan metode quasi eksprimen. Desain penelitian yang digunakan adalah One-Group Pretest-Posttest Design. Pada desain ini terdapat pretest, sebelum diberi perlakuan. Dengan demikian hasil perlakuan dapat diketahui lebih akurat, karena dapat membandingkan dengan keadaan sebelum diberi perlakuan.
Tabel 1. Desain Penelitian One-Groupe PretestPosttest Design

\begin{tabular}{ccc}
\hline Pre-test & Treatment & Post-test \\
\hline $\mathrm{O}_{1}$ & $\mathrm{X}$ & $\mathrm{O}_{2}$ \\
\hline
\end{tabular}

Keterangan :

$\mathrm{O}_{1}$ : Nilai Pre-test (sebelum diberi perlakuan).

$\mathrm{O}_{2}$ : Nilai Post-test (setelah diberi perlakuan).

$X$ : Perlakuan yang diberikan oleh model

pembelajaran inkuiri terbimbing.

Teknik pengambilan sampel dalam penelitian ini adalah Purposive Sampling adalah teknik penentuan sampel dengan pertimbangan tertentu. Pertimbangan yang menyebabkan dipilihnya kelas XI IPA 3 sebagai sampel karena kelas ini memiliki rata-rata kemampuan kognitif yang sama.

Dalam penelitian ini teknik pengumpulan data yang digunakan adalah tes yang digunakan dalam penelitian ini adalah tes tertulis kemampuan kogntif. Teknik tes dibuat oleh peneliti yang diberikan kepada responden untuk mengukur kemampuan berpikir kritis siswa dalam pembelajaran fisika yaitu berupa pre-test dan post-test yang dilakukan pada akhir pembelajaran suhu dan kalor. Soal pre-test dan post-test berbentuk essai (uraian) sebanyak 10 soal.

Teknik analisis data dengan menggunakan uji $N$-Gain dan Uji t-berpasangan. Tingkat keberhasilan Pretest dan Posttest dapat di identifikasi dengan mencari $\mathrm{N}$-Gain. N-Gain adalah selisih antara nilai Pretest dan Posttest. $\mathrm{N}$-Gain menunjukkan peningkatan berpikir kritis siswa setelah pembelajaran yang telah dilakukan oleh guru. Pengujian dilakukan untuk aspek kognitif, yaitu dengan menggunakan rumus sebagai berikut :

$$
N-\text { Gain }=\frac{S_{\text {posttest }}-S_{\text {pretest }}}{S_{\text {maksimum }}-S_{\text {pretest }}}
$$

Keterangan :

$N$-Gain : Keuntungan atau Peningkatan

Sposttest : Jumlah Skor Posttest

Spretest : Jumlah Skor Pretest

Smaksimum : Jumlah Skor Maksimum

Disini dijelaskan bahwa $N$-Gain adalah gain yang dinormalisasi, $S_{\text {maksimum adalah skor }}$ maksimum (ideal) dari tes awal dan tes akhir,

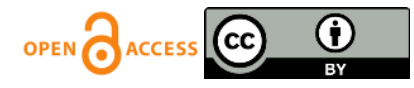


Pengaruh Model Pembelajaran

Sposttest adalah skor tes akhir, sedangkan Spretest adalah skor awal. Tinggi rendahnya gain yang normalisasi ( $N$-Gain) dapat dikategorikan sebagai berikut :

Tabel 2. Identifikasi Tingkat Keberhasilan Pretest-

$$
\text { Posttest }
$$

\begin{tabular}{cc}
\hline Nilai & Kategori \\
\hline $\mathrm{g}>0,7$ & Tinggi \\
\hline $0,3 \leq \mathrm{g}<0,7$ & Sedang \\
\hline $0 \leq \mathrm{g}<0,3$ & Rendah
\end{tabular}

Peneliti menggunakan Uji-t berpasangan untuk mengetahui pengaruh model pembelajaran OIDDE terhadap kemampuan berpikir kritis siswa kelas XI IPA 3 SMA Negeri 2 Berau, terhadap data skor pre-test dan post-test pada kelas yang diuji coba. Pengujian uji-t perlu memperhatikan langkah-langkah dalam menjawab hipotesis sebagai berikut Hipotesisnya adalah :

$$
H_{0}: \mu_{1}=\mu_{2}
$$

Untuk menguji hipotesis maka hipotesis yang diajukan terlebih dahulu di dihilangkan menjadi hipotesis uji $\left(\mathrm{H}_{0}\right)$ yang berbunyi :

$\mathrm{H}_{0}$ : Tidak terdapat peningkatan berpikir kritis siswa setelah diterapkannya model pembelajaran OIDDE.

Secara sistematis menggunakan rumus sebagai berikut :

Keterangan :

$$
t=\frac{\overline{x d}-\mu}{S d / \sqrt{n}}
$$

$\mathrm{d}=$ Selisih $x_{1}-x_{2}$

$\mathrm{n}=$ Jumlah sampel

$x d=$ Rata-rata deviasi

$\mathrm{Sd}=$ Standar deviasi dari $\mathrm{d}$

$\mu=$ Nilai rata-rata perbedaan deviasi

Pengujian melalui Uji-t dengan membandingkan t-hitung dengan t-tabel pada taraf nyata $\alpha=0,05$. Pengambilan keputusan pada Uji-t berpasangan. Jika nilai probabilitas (thitung $>\mathrm{t}$-tabel) maka terdapat hubungan $\mathrm{H}_{0}$ dan $\mathrm{H}_{\mathrm{a}}$ yang signifikan antara model pembelajaran OIDDE terhadap kemampuan berpikir kritis siswa pada data pretest dan posttest dengan probabilitas lebih kecil dari $5 \%(p<0,05)$. Sedangkan jika nilai probabilitas (t-hitung < ttabel) maka tidak dapat pengaruh yang signifikan antara model pembelajaran OIDDE terhadap kemampuan berpikir kritis siswa pada data pretest dan posttest.

\section{HASIL DAN PEMBAHASAN}

\section{HASIL}

Penelitian dilakukan di SMA Negeri 2 Berau dari tanggal 26 September 2019 sampai 10 oktober 2019. Hasil penelitian dari pembelajaran Fisika pada materi Suhu dan Kalor digunakan untuk mengetahui ada atau tidaknya pengaruh model OIDDE terhadap peningkatan berpikir kritis siswa kelas XI IPA 3 dengan jumlah siswa 32 orang. Hasil penelitian meliputi data hasil belajar siswa kelas XI IPA 3 pada materi suhu dan kalor yang diukur menggunakan instrumen tes tertulis uraian. Nilai pretest merupakan nilai kemampuan berpikir kritis awal siswa atau sebelum diterapkan model, sedangkan nilai posttest merupakan kemampuan berpikir kritis akhir siswa setelah diterapkannya model pembelajaran OIDDE. Pada posttest akan diperoleh data penelitian yang diuji dan dianalisis untuk menjawab rumusan masalah yang telah ditetapkan sebelumnya.

\section{a. Perolehan Nilai Pretest}

Sebelum diterapkan pembelajaran dengan model pembelajaran OIDDE (pretest), hasil tes tertulls siswa memperoleh nilai dengan rata-rata 12,31 dengan deviasi standar 6,34. Data analisis berpikir kritis siswa (pretest) dapat digolongkan dalam kategori penilaian berpikir kritis siswa sebagai berikut.

Tabel 3. Persentase Penilaian Kategori Berpikir Kritis Siswa (Pretest)

\begin{tabular}{lcc}
\hline Kategori & Jumlah Siswa & $\begin{array}{c}\text { Persentase } \\
(\%)\end{array}$ \\
\hline Baik Sekali & 0 & 0 \\
\hline Baik & 0 & 0 \\
\hline Cukup & 0 & 0 \\
\hline Kurang & 0 & 0 \\
\hline Kurang sekali & 32 & 100 \\
\hline
\end{tabular}

b. Perolehan Nilai Posttest

Hasil peserta didik setelah diterapkan model pembelajaran OIDDE (posttest) memperoleh nilai rata-rata 61,31 dengan

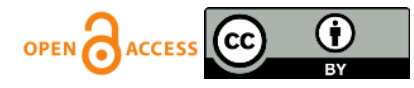


Pengaruh Model Pembelajaran

standar deviasi 21,00. Hal ini menunjukkan bahwa setelah diberikan perlakuan terdapat peningkatan dari sebelum diberikan perlakuan. Hasil posttest dan rata-rata yang telah didapatkan tersebut kemudian dikategorikan penilaian berpikir kritis siswa sebagai berikut.

Tabel 4. Persentase Penilaian Kategori Berpikir Kritis Siswa (Posttest)

\begin{tabular}{lcc} 
Kategori & Jumlah Siswa & $\begin{array}{c}\text { Persentase } \\
(\%)\end{array}$ \\
\hline Baik Sekali & 0 & 0 \\
\hline Baik & 0 & 0 \\
\hline Cukup & 0 & 0 \\
\hline Kurang Sekali & 32 & 100 \\
\hline
\end{tabular}

\section{c. Perolehan $\mathrm{N}$-Gain}

Peningkatan nilai pretest dan posttest dapat diidentifikasi dengan menghitung skor $\mathrm{N}$-gain. Rata-rata $\mathrm{N}$-gain siswa pada pokok bahasan Suhu dan Kalor disajikan pada tabel berikut:

Tabel 5. Nilai Rata-rata N-Gain Siswa

\begin{tabular}{ccccccc}
\hline Pretest & SD & $\begin{array}{c}\text { Postte } \\
\text { st }\end{array}$ & SD & N-Gain & Kriteria \\
\hline 12.31 & 6.34 & 61.31 & 21.00 & 0.56 & sedang \\
\hline
\end{tabular}

Hasil analisis data bila digambarkan dengan diagram batang perolehan rata-rata pretest dan posttest yakni sebagai berikut:

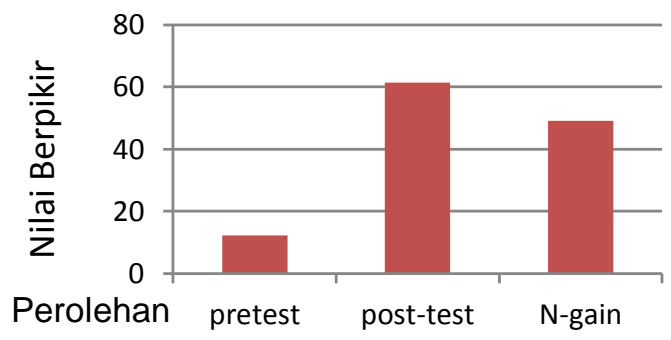

Gambar 3. Diagram Perolehan Nilai Rata-rata Pretest-Posttest

d. Analisis Pengaruh Model Pembelajaran OIDDE Terhadap Peningkatan Berpikir Kritis

Untuk mengetahui pengaruh model pembelajran OIDDE terhadap peningkatan berpikir kritis di SMAN 2 Berau. Uji-t berpasangan dilakukan dengan menggunakan aplikasi SPSS untuk mengetahui apakah terdapat perbedaan yang signifikan antara dua rata-rata dari hasil pretest maupun posttest pada suatu kelompok yang sama. Hasil analisis yang diperoleh dengan menggunakan Uji-t berpasangan adalah sebagai berikut:

Tabel 6. Hasil Uji-t berpasangan Perolehan Pretest dan Post-test

\begin{tabular}{lc}
\hline \multicolumn{2}{c}{ Test Statistic } \\
& Pretest - Posttest $^{\text {a }}$ \\
\hline$T$ & $-15,16$ \\
$D f$ & 31 \\
Asymp. Sig. (2-tailed) & .000 \\
\hline
\end{tabular}

Tabel menunjukkan bahwa nilai $p$-value yang diperoleh 0.00 yakni kurang dari taraf signifikansi yakni 0.05 , sehingga dapat sisimpulkan bahwa $\mathrm{H}_{a}$ diterima, sehingga terdapat peningkatan berpikir kritis setelah diterapkannya model pembelajaran OIDDE.

\section{PEMBAHASAN}

Tujuan dari penelitian adalah untuk mengetahui pengaruh model Pembelajaran OIDDE terhadap Peningkatan Berpikir Kritis Siswa Kelas XI IPA 3 SMAN 2 Berau pada materi suhu dan kalor tahun ajaran 2019/2020. Pengambilan sampel dilakukan dengan teknik adalah Purposive Sampling adalah teknik penentuan sampel dengan pertimbangan tertentu.

Tes awal (pretest) berupa essai sebanyak 10 soal yang dikerjakan oleh siswa yang bertujuan untuk mengetahui tingkat berpikir kritis awal siswa pada materi suhu dan kalor. Diperoleh nilai rata-rata pretest siswa yaitu 12.31 , kemudian nilai rata-rata pretest siswa di kategorikan berdasarkan kualifikasi kemampuan berpikir kritis siswa seperti pada Tabel 3 didapatkan 32 siswa termasuk dalam kategori kurang sekali. Bila digrafikkan seperti Gambar 1 pada grafik cenderung berada pada kualifikasi kurang sekali, hal ini menunjukan bahwa masih kurang berpikir kritis awal siswa pada materi suhu dan kalor.

Kemudian siswa diberikan posttest atau sebuah tes akhir setelah menerima 
Pengaruh Model Pembelajaran

pembelajaran menggunakan model pembelajaran OIDDE pada materi Suhu dan Kalor dan didapatkan hasil nilai rata-rata posttest siswa kelas XI IPA 3 SMAN 2 Berau sebesar 61.31. Hal ini menunjukkan bahwa setelah diberikan perlakuan terdapat peningkatan dari sebelum diberikan perlakuan model pembelajaran OIDDE. Kemudian nilai rata-rata posttest di kategorikan berdasarkan kategori berpikir kritis siswa seperti yang bisa dilihat pada Tabel 4 didapatkan tujuh siswa termasuk dalam kategori baik sekali, tujuh siswa termasuk dalam kategori baik, lima siswa termasuk dalam kategori cukup, lima siswa termasuk dalam kategori kurang, dan delapan siswa termasuk dalam kateori kurang sekali. Apabila di grafikkan seperti Gambar 2 dilihat bawa grafik cenderung mearata. Tujuh siswa yang masuk dalam kategori baik sekali dikarenakan pada saat dilakukan kegiatan belajar mengajar mereka terlihat aktif dan memperhatikan apa yang dijelaskan oleh penulis pada saat menjelaskan materi begitu pula pada saat praktikum siswasiswa tersebut aktif dan memperhatikan apa yang dijelaskan oleh penulis dan bertanya ketika berdiskusi setelah melaksanakan praktikum tetapi tidak semua terlihat aktif adapun sebagian siswa yang lebih cenderung suka bercanda dengan teman sebangkunya tetapi penulis langsung mengkondisikan siswa jika ada terlihat yang kurang memperhatikan apa yang disampaikan oleh penulis. Lalu ada delapan siswa termasuk dalam kategori kurang sekali merupakan siswa yang pada saat pembelajaran kurang memperhatikan, kurang berpartisipasi dalam pembelajaran dan pada saat melaksanakan kegiatan belajar mengajar siswa ini jarang sekali hadir pada saat pembelajaran fisika dan membuat mereka ketinggalan bahan materi yang diajarkan sehingga kemampuan berpikir kritisnya tidak berkembang maksimal.

Secara khusus pengaruh dari model pembelajaran ini dilihat dari kenaikan $\mathrm{N}$-gain siswa yang memiliki rata-rata nilai sebesar 0,56 yang menggambarkan kenaikan $\mathrm{N}$-gain tersebut masuk kedalam kriteria sedang setelah diberikannya perlakuan. Sesuai hasil perhitungan pada Tabel 5 yang menunjukkan kenaikan $\mathrm{N}$-gain terhadap kemampuan berpikir kritis siswa berdasarkan nilai pretest dan posttest.

Hasil penelitian menunjukan bahwa model pembelajaran OIDDE dalam pembelajaran fisika berpengaruh signifikan terhadap kemampuan berpikir kritis siswa. Pembelajaran yang melibatkan aktivitas siswa dalam pemecahan masalah melalui mengajukan masalah, menyajikan hipotesis dengan kegiatan eksperimen atau percobaan dan menganalisis data dapat melatih kecakapan kemampuan berpikir kritis siswa selain itu model pembelajaran OIDDE mampu melatihkan keterampilan intelektual, berpikir kritis, dan mampu memecahkan masalah secara ilmiah. Proses pemecahan masalah dikaitkan dengan permasalahan sehari-hari, sehingga siswa memiliki kesempatan untuk belajar memecahkan masalah yang dihadapinya di kehidupan seharihari dan masalah yang berasal dari fenomenafenomena nyata yang mengakibatkan siswa akan terlibat dalam perilaku berpikir kritis. Hal ini membuktikan bahwa pembelajaran dengan menggunakan model OIDDE berdampak positif bagi perkembangan mental dan cara belajar siswa.

Pada model pembelajaran OIDDE tersebut terdapat lima tahapan yaitu orientation, pada tahap ini peserta didik diharapkan menganalisis permasalahan dikehidupan sehari-hari, selanjutnya identify yaitu peserta didik diminta untuk mengidentifikasi permasalahan yang ada, lalu ada tahap discussion yaitu peserta didik setelah mengidentifikasi permasalahan yang ada, selanjutnya ada tahapan decision yaitu keputusan dimana peserta didik diminta untung mengambil keputusan terhadap permasalahan yang telah diberikan yang terakhir ada tahap engage in behavior yang di maksud pada tahap ini pesrta didik menyimpulkan pendapat mereka terhadap permaslahan yang telah diberikan. Pada kelima tahap tersebut sangat mempengaruhi dalam meningkatkan berpikir kritis siswa di mana pada soal yang diberikan pada tahapan $\mathrm{C} 4$ yaitu soal menganalisis dengan mengunakan model tersebut siswa dapat menganalisis yang terdapat pada soal yang diberikan. Adapun manfaat yang didapat 
Pengaruh Model Pembelajaran

dalam pembelajaran di kelas yang mana telah dipaparkan peneliti pada bab 1 dimana model pembelajaran ini dapat menciptakan suasana belajar lebih kondusif, hidup dan menarik, sehingga pada saat pembelajaran berlangsung peserta didik dapat menerima pembelajaran dengan baik, dan juga terbentuknya situasi kooperatif dalam pembelajaran, sehingga terbentuknya atmosfir pembelajaran yang positif, sebagaimana situasi pembelajaran yang kooperatif akan menciptaan dua tanggung jawab pada para siswa yaitu mempelajari materi yang ditugaskan dan memastikan bahwa semua anggota kelompok benar-benar mempelajari materi tersebut.

Berdasarkan analisis yang telah dilakukan terhadap penelitian ini dapat disimpulkan bahwa penggunaan model pembelajaran OIDDE dapat meningkatkan berpikir kritis siswa meningkat. Hal ini sejalan dengan beberapa penelitian yang telah dilakukan sebelumnya (Husamah, Fatmawati, \& Setyawan, 2017) yang juga memberikan hasil penelitian yang menunjukkan bahwa model pembelajaran OIDDE dapat meningkatkan kemampuan berpikir kritis siswa.

Hasil analisis data dengan pembelajaran model OIDDE ternyata menghasilkan nilai yang signifikan didapat dari perhitungan menggunakan uji-t berpasangan. Berdasarkan Tabel 6 memperoleh nilai signifikansi 0.00 lebih kecil daripada 0.05 , sehingga dengan demikian dapat disimpulkan bahwa terdapat peningkatan berpikir kritis setelah diterapkannya model pembelajaran OIDDE.

\section{PENUTUP}

Berdasarkan hasil penelitian dan analisis data yang telah dilakukan di SMA N 2 Berau di kelas XI IPA 3 mengenai kemampuan berpikir kritis siswa dengan menggunakan model pembelajaran OIDDE pada materi suhu dan kalor maka dapat ditarik kesimpulan bahwa, pada penelitian ini terdapat pengaruh model pembelajaran OIDDE terhadap kemampuan berpikir kritis siswa pada materi suhu dan kalor.

Berdasarkan temuan-temuan yang diperoleh selama penelitian, maka peneliti menyarankan: 1) bagi siswa, agar terus belajar, berlatih, serta lebih ditingkatkan kemampuan literasinya sehingga dapat diperoleh hasil belajar yang lebih baik lagi, 2) bagi guru, pemberian masalah dan pemecahahan masalah yang diberikan oleh guru pada saat belajar mengajar dengan bimbingan dari guru akan lebih baik bila dilakukan secara bertahap dan dilaksanakan setiap pertemuan, 3) bagi sekolah, diperlukan sarana dan prasarana pendukung dalam kegiatan pembelajaran agar diperoleh kegiatan pembelajaran yang lebih baik, 4) bagi peneliti, diharapkan dapat mengembangkan berbagai penelitian lainnya dengan model pembelajaran yang dapat meningkatkan minat siswa dalam mengikuti pembelajaran fisika.

\section{DAFTAR PUSTAKA}

Hudha, A. M., Amin, M., Sumitro, S. B., \& Akbar, S. (2016a). Model pembelajaran OIDDE untuk pembelajaran bioetika. Makalah Seminar Nasional. Seminar Nasional Pendidikan Biologi Di Prodi Pendidikan Biologi-FKIP Universitas Muhammadiyah Malang, 26.

Hudha, A. M., Amin, M., Sutiman, B. S., \& Akbar, S. (2016b). Telaah model-model pembelajaran dan sintaksnya sebagai upaya pengembangan model pembelajaran 'OIDDE.' Jurnal Pendidikan Biologi Indonesia, 2(2), 109-124.

Husamah, H., Fatmawati, D., \& Setyawan, D. (2017). Model pembelajaran OIDDE pada matakuliah pengetahuan lingkungan untuk meningkatkan keterampilan berpikir kritis mahasiswa calon guru biologi. Jurnal Bioedukatika, 5(2), 73-85.

Pemerintah Republik Indonesia. (2013). UndangUndang RI Nomor 20 tahun 2003 tentang Sistem Pendidikan Nasional Pasal 1. Jakarta.

Setyawan, D. (2017). Penerapan model pembelajaran OIDDE pada matakuliah zoologi vertebrata untuk meningkatkan kemampuan berfikir kritis dan hasil belajar mahasiswa pendidikan biologi Universitas Muhammadiyah Malang. Research Report.

Husamah, Pantiwati, Y., \& Hudha, A.M. (2017). OIDDE Learning Model through Integrated Field Studies Abroad to Develop Ethical Decision Skills of Candidate Biology 
Teachers: Indonesian Perspective. Educational Process: International Journal, 6(4), 7-19. 